\title{
Global Value Chains and Market Formation Process in Emerging Export Activity: Evidence from Ethiopian Flower Industry
}

By

Mulu Gebreeyesus

Tetsushi Sonobe

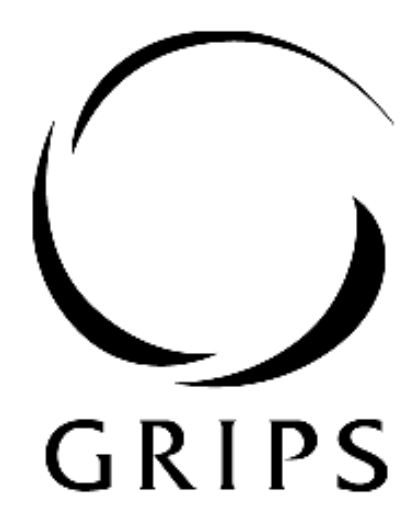

National Graduate institute FOR POLICY STUDIES

National Graduate Institute for Policy Studies

7-22-1 Roppongi, Minato-ku,

Tokyo, Japan 106-8677 


\title{
Global Value Chains and Market Formation Process in Emerging Export Activity: Evidence from Ethiopian Flower Industry
}

\author{
Mulu Gebreeyesus \\ United Nations University Maastricht Economic and Social Research and Training \\ Centre on Innovation and Technology (UNU-MERIT), the Netherlands \\ Tetsushi Sonobe \\ National Graduate Institute for Policy Studies (GRIPS), Japan
}

August 2011

\begin{abstract}
This paper provides a case study of the Ethiopian flower export industry which successfully emerged at time when the EU market (main destination) was already characterized by increasingly stringent standards and delivery requirements. Entering this market required a multitude of capabilities at firm, sector and national levels. Several of these capabilities were absent or weak in the domestic market when the new activity kicked off. The paper analyzes how the capabilities of individual firms and the industry at large co-evolved and the role of various actors in the 'market formation' process.
\end{abstract}

JEL Classification: O12, O13, O19

Keywords: Africa, Ethiopia, global value chain, market formation, cut-flower industry 


\section{Introduction}

Developing countries have been advised for a long time to adopt a diversification strategy into high-value non-traditional agriculture exports as a reaction to the long-term declining pattern of prices in traditional exports. Unlike other regions, export diversification performance in Sub-Saharan Africa (SSA, hereafter) has been generally unsatisfactory. Recently, a few countries have made some progress diversifying their exports into non-traditional horticulture products such as cut flowers and ornamentals, fruits, and vegetables. The major destination of SSA countries' horticulture exports is the European Union (EU) market. For example in 2006, SSA exported about USD 2.06 billion of fresh vegetables and fruits, of which about 63 per cent were directed to the EU market. Over 90 per cent of the euro 423 million worth of cut-flowers exports from SSA in the same year were also destined to the EU market (UNCTAD, 2008).

The EU market for fresh horticulture has become increasingly complex, starting in the late 1980s. This was mainly driven by two inter-related developments: a dramatic increase in the share of supermarkets in the value chain and shifting public attitudes towards food safety, environment and labour conditions. Horticulture exports to the EU market face increasingly stringent standards and additional value chain specific regulations related to consistency in volume, quality and timing of delivery.

A number of studies have analyzed the effect of these developments on exports from SSA (for example Dolan and Humphrey, 2000; Jaffee, 2003; Gibbon and Ponte, 2005; Henson and Jaffee, 2006). Most of the studies apply the Global Value Chain (GVC, hereafter) framework and focus mainly on the impact on small producers in the chain. They give less attention to local efforts in enhancing their capacities to meet the increasing demands and standards. Moreover, almost all studies deal with already 
existing industries and countries in the EU export market. We know little about how it has been possible for firms/industries to develop capabilities and successfully enter the global value chain in the new era of growing power of global buyers and standards. Furthermore, there is a dearth of empirical studies concerning the impact of changes in governance or standards on SSA flower exports. ${ }^{1}$

In this study, we examine the recent emergence of the Ethiopian flower industry and its relative success. Ethiopia started to enter the flower export market in the mid1990s at the time when the EU market was much more demand driven, and as a result increasingly stringent standards and regulations had been instituted. In less than a decade, the country became the fifth largest non-EU flower exporter to the EU market and the second largest exporter from Africa, surpassing all early exporter countries except Kenya. There are only a few studies systematically examining the successful emergence of the flower industry in Ethiopia. Belwal and Chala (2008) analyze the catalysts and barriers to the growth of the flower industry, focusing on the promotional activity of the government and environmental impact. Melese and Helsing (2010) examine the impact of foreign dominance, particularly of Dutch firms, in the sector in terms of the extent of endogenisation (a process of building local capabilities). Both of these studies are based on a small sample (only 10 farms in the former case and eight farms in the later), and thus mainly depend on secondary and aggregate data.

The objective of the current study is to analyze how capabilities in the Ethiopian flower industry were formed and took shape in an effort to link to the EU market while meeting the complex standards and trading procedures this market requires. The novelty

\footnotetext{
${ }^{1}$ An exception in this regard is Riisgaard (2009), who examines the opportunities and challenges that private social standards pose for labour organizations in the Kenya and Tanzania flower industries
} 
of this study is its reliance on a unique data set that covers all operational flower farms in $2008 .^{2}$ Data was collected from 64 flower farms out of the 67 operating at that time, a response rate of 96 per cent. The interviews were based on a structured questionnaire where the main informants were owners or managers of the farms. This study also uses documents from the government and the industry association as well as interviews with government officials, association leaders, and owners of the early entrant firms. These interviews were conducted by the first author prior to the farm survey and also as a follow-up in 2010.

The next section gives an overview of the evolution of the Ethiopian flower industry. Section 3 describes the structural changes that have been taking place in the EU floriculture market. Section 4 briefly describes the market formation approach which is then used in section 5 to explain the successful emergence of the industry. Section 6 analyzes differences in capabilities between firms supplying auction and direct sales market channels before concluding.

\section{Overview of the evolution of the Ethiopian flower industry}

Commercial flowers business is a new export venture for Ethiopia. A modern, export-oriented and private sector based floriculture industry began to emerge in the mid-1990s. Two domestic entrepreneurs started the experimentation to grow and export summer flowers to the EU market. Unfortunately, these first movers ceased their production of flowers after a few years for different reasons. In 1999, Golden Rose - a

\footnotetext{
${ }^{2}$ This survey was a collaborative project between the Ethiopian Development Research Institute (EDRI) and the Japanese National Graduate Institute for Policy Studies (GRIPS). It was administered by the authors and about eight enumerators were dispatched to carry out the interviews.
} 
foreign owned firm and so-called pioneer - started rose production using a modern steel structure greenhouse. Between 2000 and 2002, another four farms entered the industry, of which Ethiopians owned three. ${ }^{3}$

According to our discussion with government officials and leaders of the industry association, the government was unaware of the major opportunity offered by the flower industry until the end of 2002. The export promotion strategy that was adopted by the incumbent government in 1998 makes no mention of the flower industry, despite an extended list of priority sectors for support. The early entrants faced a number of difficulties particularly related to logistics, land and finance. In 2002, they formed an association called Ethiopian Horticulture Producers and Exporters Association (EHPEA) and started to seek government support. Consequently, the government decided to promote the sector and set five-year targets. It provided a generous support package, identifying three areas for intervention: transport coordination (air freight), access to land, and provision of long-term credit. Moreover, the government engaged in activities to attract domestic and foreign investors.

Domestic and foreign investment increased following the government's generous support and concerted advocacy activities in combination with the association. Table 1 reports the evolution of the flower industry in terms of number of firms and exports since 2000. The number of firms increased sharply, rising from 10 firms in 2004 to 81 firms by the end of 2008. Prior to 2004, the sector only generated USD 3.7 million. By 2008, this increased to nearly USD 100 million, and the sector became among the four top foreign exchange earning commodities for the country.

\footnotetext{
${ }^{3}$ See Gebreeyesus and Iizuka (2010) for further details on the emergence of the industry.
} 
From 2004, the number of foreign-owned firms and joint ventures between foreigners and Ethiopians surpassed the number of purely domestic-owned firms. Out of the 67 farms that were operating in 2007, 42 per cent were fully foreign owned, 22 per cent were joint ventures, and 36 per cent were fully domestic owned. Dutch, Indian and Israeli entrepreneurs constitute the majority of foreign owned firms (including joint ventures). Most farms (64 per cent) are located in the highlands (at altitude above 2000 meters above sea level) and about $50 \mathrm{~km}$ radius of the capital city, Addis Ababa, where the main airport is to be found. ${ }^{4}$

\section{Structural change in the EU horticulture market}

The European Union is one of the largest floriculture markets accounting for more than half of world imports. In 2006, the total imports (intra- and extra-EU) of cut flowers and foliage in the EU (EU-25) were about EUR 3.4 billion (CBI, 2007). SSA share in the EU cut-flower market has been on the rise in the last couple of decades. In 2007 six SSA countries (Kenya, Ethiopia, Zimbabwe, Uganda, Zambia, and South Africa in order) were among the top ten extra-EU cut-flower suppliers, accounting for about 51 per cent (Gebreeyesus and Iizuka, 2010).

Structural changes similar to those in fresh vegetable and fruits marketing are taking place in the EU flower marketing channel. One dimension of this change is the increasing role of direct sales at the expense of auctions. The number of flower auctions has been on the decline partly as a result of mergers between auctions. In Europe there

\footnotetext{
${ }^{4}$ The terms 'farms', 'firms' and 'enterprises' are used synonymously hereafter, given that all flower farms in the Ethiopian industry are separately managed, individual legal entities.
} 
are about 10 auctions currently, but the two most relevant auctions with respect to flowers exported from developing countries (FloraHolland and Aalsmeer) are located in the Netherlands. In 2007, these remaining two auctions merged (CBI, 2007). The declining market share of auctions is mainly driven by the growing role of supermarkets. According to Wijnands (2005), supermarkets' share in cut flowers market in 2004 was 64 per cent in England, 46 per cent in Denmark, and 25 per cent in Netherlands. Their share has been growing in recent years (CBI, 2007).

The increasing role of direct sales and particularly supermarkets has a significant impact on the governance of the global value chain for horticulture. Based on their concentrated power supermarkets exercise more control in the value chain. One major motive for supermarkets exercising more coordination is the need to meet regulatory requirements and the public pressure on safety, environment and labor conditions. Arms-length type of trade cannot ensure compliance unless standards are fully codified and can be certified by reliable service providers (Altenburg, 2006). Consequently, supermarkets undertook initiatives to formulate standards governing the horticultural trade, which have become institutionalized by European Union as formal regulations (Labaste, 2005). For example, GlobalGAP (formerly EUREPGAP) and the Milieu Project Sierteelt (MPS) are widely applied standards in the flower market. These standards cover food safety concerns, labor and environmental conditions. ${ }^{5}$

The supermarkets' drive towards explicit coordination in the value chain also emanates from their competitive strategy. Supermarkets attract customers and compete

\footnotetext{
${ }^{5}$ Among others, these standards require full traceability of all products; professional administration staff for comprehensive record keeping; additional facilities to separately store chemicals, fertilizers, packaging; restricting the use of some type of chemical; hygiene precaution; minimum working standards for workers; and announced and un-announced on-farm audit (Labste, 2005).
} 
by introducing new items (differentiation), emphasizing quality, providing consistent year-round supply, and increasing the process of products to provide fresh produce that required little or no preparation prior to using (Gereffi, Humphrey and Sturgeon, 2005). To achieve this objective, they impose additional bilateral regulations such as large range of varieties, consistency in volume, quality and timing on their suppliers (Dolan and Humphrey, 2000), hence, increasingly pushing risks and costs upwards to suppliers and producers (Labaste, 2005).

There is increasing debate on the impacts of the change in governance and associated standards and delivery requirements on suppliers from developing countries. ${ }^{6}$ The existing studies in SSA countries provide evidence for exclusion of smallholders and consolidation of a few large firms in fresh food exports to EU market as a result of the recent governance changes in the global value chain and increasing standards (for example Dolan and Humphrey, 2000 for Kenya and Zimbabwe vegetables; Jaffee, 2003 for Kenya vegetable; Henson and Jaffee, 2006 for Ghanaian fruit and vegetable; and Maertens and Swinnen, 2006 for Senegal vegetables). Most of these studies apply the GVC approach, which emphasizes the role of suppliers and clients arranged along the value chain, and thus mainly market-based linkages.

The limitation of this approach is that it pays less attention to horizontal linkages and the institutional environment, which are vital in the enhancement of private firms' compliance with the new requirements. UNIDO (2005) argues that responding to the new challenges involves raising domestic capacity at all levels (i.e. firm, sector, and nation) to interact with international systems, enhancing the knowledge base, and building legitimacy and trust in the domestic institutions. The GVC literature has also

\footnotetext{
${ }^{6}$ Altenburg (2006) and Maertens and Swinnen (2006) have excellent reviews on this debate.
} 
little to say about the successful formation of new industries in the context of changes in the governance of global value chains. Understanding the response of developing countries, therefore, needs a broader framework than GVC.

\section{Market formation: an innovation systems perspective}

The Innovations Systems (IS) perspective combines both the market-based linkages along the value chain and other horizontal linkages needed for innovation and capacity building (Edquist, 2004; Hall, Mytelka and Oyelaran-Oyeyinka, 2007). This framework has been widely applied recently and increasingly refined. Hekkert et al. (2007) and Bergek et al. (2008) propose a functionality of innovation systems analysis that focuses on the most important processes that need to take place in innovation systems to lead successfully to technology development and diffusion. They identified seven key processes: entrepreneurial experimentation, knowledge development and diffusion, influence on the direction of search, market formation, legitimation, resource mobilization, and development of positive externalities. According to them, for an innovation system to evolve and perform well, these seven functional requirements must be fulfilled. There are some attempts to apply the functional framework for emerging industries in developing countries (e.g. Jocobsson and Bergek, 2006; Gebreeyesus and Iizuka, 2010). This article focuses on one specific aspect of the discovery process market formation. 
In the context of export-oriented products in a catching-up economy market formation is basically about linking to existing international markets. ${ }^{7}$ However, access to international markets is usually a big challenge for developing country firms. First, the global market for the agricultural and labour intensive manufacturing products is characterized by intense competition due to growing supply from developing countries. A mere comparative advantage in certain resources is not enough and newcomers might need to identify niche markets. Second, in developing countries there is a large gap between the existing and required knowledge and capabilities for supplying the export market. This might be due to the fact that producers from developing countries have the characteristics of 'latecomer' firms (i.e. technologically behind) and the exported products frequently do not (yet) have significant demand in their domestic markets (Humphrey and Schmitz, 2004). Third, many kinds of the developing country export products (agriculture and labour intensive manufacturing products) face various trade restrictions in exporting to developed countries. Despite recent initiatives to reduce these restrictions and improve access, entering into these markets remains complicated due to other developments such as the increasing power of global buyers and the growing trend of public and private standards and regulations.

Hence, successfully entering into the global buyers dominated market demands not only identifying a niche market but also higher capabilities at the supply base to ensure consistent, diversified and quality products that comply with regulatory requirements. This in turn requires, among others, access to production technology, skilled personnel,

\footnotetext{
${ }^{7}$ Domestic firms may also experiment in the local market if the market for that product exists locally. In such cases market formation might involve domestic market protection for firms to buildup capacity and adequate size to be able to compete with imports and abroad as it was found in the case of Korean Machinery industry (Jaccobson and Bergek, 2006).
} 
marketing knowledge, improved infrastructure and logistics, and quality control and accreditation systems, which we refer to here as the major factors that drive the market formation. Since, the activities are new there exists a weak or no market for many specific inputs (e.g. workers with specific skill, logistic system, procurement and marketing systems, standards and regulatory rules) for the specific activity (Hausmann and Rodrik, 2006). Market formation, therefore, involves a wide array of capacity building efforts to overcome these and other impediments. This endeavour requires coordination among firms and collaboration between the private and public sectors.

The lack of coordination might slowdown or block the discovery process altogether. To take an example from the flower industry, the failure of the flower export experiment in the first phase (1963-73) in Ecuador was mainly due to absence of coordination particularly solving the uncertainties caused by phytosanitary problems and air transport to the United States (Arbelaez, Melendez, and Leon, 2007). However, in some cases, the uncertainties at the initial stage might be solved if foreign investors with well established expertise and distribution channels pioneer the discovery process as in the case of Colombian and Kenyan flower industries. In the former case flower export discovery was driven by Floramerica a US owned company with wide expertise and knowledge of production and marketing distribution in the USA flower market (Arbelaez, et al., 2007). Similarly in Kenya, initial development of the flower sector was spurred by a Danish Company (Dansk Chrysanthermum Kultur) in an effort to expand its European flower-production base to locations with lower labor costs and longer growing seasons, which later attracted other investors, mostly foreign (Whitaker and Kolavalli, 2006). Even in those cases, coordination was particularly required in the 
diffusion process. Most importantly, attracting such capable investors might not always be easy.

What types of coordination of actors did the market formation process in the Ethiopian flower industry demand? What capacities were required to enter the European market and to what extent and how were these capacities built? In addressing these and other related questions, we focus on the following four market formation mechanisms: (1) Production technology and skilled labour: (2) Marketing knowledge and export channels: (3) Infrastructure and logistics: and (4) Compliance with regulations and standards in export markets. For each of these mechanisms, we analyze the role of different actors including firms, industry associations, the government, and donors.

\section{Analysis of the Ethiopian flower industry market formation process}

\subsection{Production technology and skilled labour}

One of the key challenges of production technology in the flower industry is access to improved planting materials and adaptation to local conditions. ${ }^{8}$ Differentiation in the flower industry is mainly achieved through increasing or changing the flower varieties. The production of new varieties is highly knowledge intensive and, as a result, monopolized by a few breeders in the developed world, mainly in the Netherlands. In order to meet the rapidly changing consumer demand, flower farms in developing countries need to have access to these new varieties. Membership in the Union for the Protection of new Varieties of Plants (UPOV) is important in order to

\footnotetext{
${ }^{8}$ Access to modern equipments such as the greenhouse is also crucial and this was mainly acquired from abroad (Israel, the Netherlands, and Spain).
} 
have easy access to new and improved varieties that are required by end-markets (Joosten, 2007). Growers also have to respect the property rights and pay royalties or license fees to international breeders (Wijnands, 2005).

The main sources of new varieties for the majority of Ethiopian flower farms are international breeders through licensed royalties. According to our survey, a typical flower farm pays royalty to three companies for using their property rights. Since 2005, international breeding companies started to establish production sites in Ethiopia. By early 2008, there were six cuttings companies which produce pot plant and cut flower cuttings. They are all owned by European breeding companies and exported young plants worldwide, mainly through the order of their mother companies (Joosten, 2007). The cuttings farms also propagate new varieties for domestic sales. The entry of breeders has greatly improved the adaptability and availability of the varieties selected in the domestic market, which helped to increase the growers’ competitiveness.

Several rose farms also started to propagate for their own use and for sale to other farms. At the initial stage, planting materials were imported. Through time, the source of planting materials shows a tendency of shifting from import to local suppliers. The share of local plant materials increased from only 16 per cent in 2005 to about 50 per cent in 2007 (see Table 2).

The sector has also been highly dependent on imports for fertilizers and chemicals. Similar to the planting materials, there is an increasing trend of substituting imported fertilizers and chemicals with local ones. Initially the problem was not only that fertilizer and chemicals were mainly imported but firms had to directly engage themselves in import transactions as the mass import of agrichemicals was not allowed. This practice demanded not only managers' time but also their capital was tied up in a 
large inventory of chemical and fertilizers. Later on, the government lifted the ban on mass import and as a result few agrichemical importing companies emerged. The first company involved in importing agrichemicals was the Ethio Horti-Share Company (EHSC), which was established by the association EHPEA. Later on, Agri Sher Trading PLC, which is a subsidiary of Sher-Ethiopia (a Dutch umbrella company), also entered the input supply market.

The shortage of skilled personnel with expertise in flower production in the domestic market was an even more serious problem at the initial stage. The only expertise that could be found in the domestic market at that time were those who had some experience in the brief history of state farms in the 1980s. However, these experts were few in number and also lacked knowledge in modern production of roses in greenhouses. The early entrant farms had to look for foreign expertise. As a result, all farms which entered before 2005 recruited foreign expertise from Kenya, India and Israel, at least in their initial year.

In an effort to address the shortage in the domestic market, the firms provided inhouse training for their workers and managers using the expatriates. There was a high turnover of labour that had obtained training and some practical experience in the pioneer firms. This turnover might have helped late entrants (a positive externality), but it also made it costly for the early entrants that lost their skilled personnel. In spite of this, in-house and outside training continue to be a major activity in the sector. For example, in 2007 about 81 percent of farms offered in-house training to their agrospecialists and 50 per cent of farms did so for production workers (see Table 2). In the same year, almost half of the farms sent their agro-specialists and production workers 
for outside training. The external training was mainly organized by the industry association.

As the sector expands, production of industry specialists becomes critical. In 2007, the government, with the support of the Dutch government and the involvement of the industry association, launched a long-term capacity building project. The project includes upgrading one of the state universities (Jimma University) to train specialists in horticulture at BSc and MSc levels. Efforts also have been made to establish a Horticulture Practical Training Centre that will provide vocational training for all levels of industry employees. Consequently, two vocational training centres (one in Melkasa and the other in Holeta, both close to the flower farm clusters) are under construction.

\subsection{Marketing knowledge and export channels}

A number of African countries including Kenya, Uganda, Zambia, Tanzania, and Zimbabwe started exporting flowers earlier than Ethiopia. All these countries (except Kenya) specialized mainly in small budded roses (sweethearts and smaller intermediates), which are prone to more competition and fetch lower prices in contrast to the big-budded and large stem roses (intermediates and T-hybrid). Ethiopia is especially suited for the production of high quality T-hybrid roses. However, identifying this comparative advantage demanded some experimentation. The first two firms that entered the industry, which ceased production after only a few years in operation, were located in the low land and were only able to produce summer flower and low-value roses (sweethearts). In contrast, Golden Rose, the first successful farm and seen as the pioneer of the industry, began producing highland roses, including T-hybrid, and 
intermediates, using greenhouses. Currently the majority of farms are located on high altitude and exporting mainly intermediates and T-hybrid types of roses. The successful entry of Ethiopia in the flower-export industry may partly be explained by the ability to seize opportunities in the niche market for large-budded roses and use it to facilitate the learning process.

Cut-flower exports to the EU market are made in two ways: auction and direct sales to supermarkets and other retailers. The relative ease of accessing the auction market means that new entrants tend to begin exporting through this channel. However, at the initial stage, the lack of marketing knowledge created a lot of uncertainties for firms. Even the foreign-owned firms among the early entrants, such as Golden Rose, had no any prior experience in the flower business and had to pass through a difficult learning curve. Foreign investors that were established players in the cut flower international market and which had broad connections, such as Sher-Holland, only came to Ethiopia later, after 2003. The auction market still remains an important entry point into the EU export market for the Ethiopian industry. About 62 per cent of firms started exporting through Dutch auction as their major marketing channel (70 per cent or more) and continue to export this way (see Table 3).

The industry is increasingly engaged in diversifying market channels and destinations. According to the survey, in 2007 about two-thirds of the farms reported that they are involved in direct sales channel. The number of destination countries also increased from only two to three countries (all in Europe) in the early 2000s to about 56 globally by 2008, although over 90 per cent of exports are still destined to the EU market. The industry association played an important role in expanding the market destinations and it continues to search for new outlets. 


\subsection{Infrastructure and logistics coordination}

Flower export is highly time and process dependent. It requires improved infrastructure and logistical capabilities including air transport, post-harvest cold chain facilities, forwarding and handling services, packaging materials, information and communication technology (ICT), and quality control and certification services. Some of these capabilities are national or sectoral in nature and cannot be built or possessed by each firm or bought from the market, and thus require coordination. Below we discuss how such capabilities were formed (both at the firm and sector level) or redirected (if it existed) to support the sector market formation process, focusing on air transport, cold chain management, and handling and forwarding services.

Air transport: Given that cut-flowers must be exported by air, sufficient and guaranteed cargo space is critical. In the flower industry, the largest running cost component is airfreight charge. According to our survey results, in 2007 the average share of airfreight cost of Ethiopian flower exporters was about 21 per cent of total export sales revenue. This shows that not only space availability but also price of air transport largely affects competitiveness. Sufficient space and lower cost of freight, however, did not exist at the initial stage. This is because there were only few exporters and as a result not many carriers were interested to compete in this market. Hence, coordination was necessary.

Ethiopia's proximity to the major horticulture market, the European Union, is one major advantage in terms of transport cost. Even more advantageous was the availability of a government-owned national carrier, Ethiopian Airlines, which is renowned for its excellence in its 60 years of service (passenger and cargo) and 
extensive international flight links. In the early years, air space was normally available on passenger flights of Ethiopian Airlines and Lufthansa. However, space was not guaranteed, and prices were high. As a result, exporters incurred losses at one time or another. The government played an important role in resolving the uncertainties and coordination problems by bringing together exporters and Ethiopian Airlines. To accommodate the increasing flower export, Ethiopian Airlines leased cargo planes for exporting cut-flowers and relocated its cargo activities from Amsterdam to Liege (Belgium) in 2008. The majority (for example 87 per cent in 2007) of the flower farms use Ethiopian Airlines. ${ }^{9}$ Through time, the Ethiopian flower industry attracted more foreign carriers such as Emirates, KLM, and Etihad.

Cool chain management and handling/forwarding services: A cool chain management plays important role for maintaining the quality of cut-flower exports, given their perishable nature. It consists of a farm level pack-house, cold truck, and airport cold storage. All farms had to construct pack-houses within their premises and incurred substantial investment costs to do so. The packed flowers need to be transported through refrigerated trucks to the airport cold storage where they stay until re-loaded into the plane. However, there were no such service providers in the market until recently. As a result, about three-quarters of the farms had to buy their own cold trucks to transport their produce to the airport, while the remainder of the farms rented them from other farms. The lack of refrigerated transport service providers raised the investment requirements of individual exporters. According to our survey, investments in facilities

\footnotetext{
${ }^{9}$ The figures provided in this sub-section are based on data set from the survey (details omitted to save space).
} 
such as farm cold storage, packing shed, and trucks and vehicles on average account for about 16 per cent of total start-up investment.

According to Lubelo (2010), recently two private cold truck providers with a capacity of 11 cold trucks have started providing a shuttle service from farm to airport for growers. This is, however, not enough to satisfy the existing demand. The cold storage at the airport, which was initially sought to accommodate the horticulture industry, is also much smaller than the existing export supply and has caused long queues and delays.

The availability of handling and forwarding companies that facilitate access to cargo space and coordinate between different exporters is another key factor for maintaining timely and high quality exports. Initially there was no such service in the market. The first forwarding/handling company Ethio Horti-Share Company was established in 2004 by the industry association to collectively arrange airfreight and handle administrative issues with the airlines. A second export facilitating company called Flower Port Cargo Plc was established in 2009 by Sher-Ethiopia and Trade Path International. The forwarding and handling business is, however, still underdeveloped. The capacity of the Crop Protection Department at the Ministry of Agriculture and Rural Development that is responsible for phytosanitary monitoring, surveillance and certification is also weak. Recently, the government with its partners initiated a capacity building program to strengthen the Ethiopian Phytosanitary service.

\subsection{Compliance with international standards}


Despite efforts of the Ethiopian flower exporters to diversify their export destinations, the EU market still accounts for over 90 per cent of the total export value. One characteristic of this market is its increasing rules and standards. At the early stage, many exporters paid less attention to the required capabilities to meet the standards. However, with the expansion and maturity of the sector and increasing involvement with direct sales, pressure for compliance with standards increased. The firms requested their association to develop an industry-wide tool to respond in an effective way to the growing demands by various stakeholders for socially responsible farm management (Joosten, 2007).

The industry association recognized the need for self-regulation and initiated the development of a code of conduct in 2006. The Dutch-Ethiopian Partnership Program was instrumental in the development of the Code of Conduct. The Code, which is aligned with the international recognized standards such as MPS and GlobalGAP requirements, is divided into three levels: Bronze, Silver and Gold. The Bronze level is a minimum requirement and compulsory for a flower farm to obtain EHPEA Code of Accreditation. The Silver level sets internationally recognized standards for Good Agricultural Practices, Protection of the Environment and Responsible Employment Practices and includes requirements equivalent in content and standards to the international market labels widely used in the sector. The Gold level sets higher standards beyond the sector benchmarks (EHPEA, 2011).

Following the launch of the Code in 2007, the industry association offered extensive training to its members, starting with a pilot of 21 farms in 2007. The training courses include internal auditing, environmental risk assessment, occupational safety and health on the farm, pesticide store keeping, safe use of pesticide, crop scouting. It 
involves not only workers but also agronomists and managers from individual farms. According to Glenn (2010), the majority of the farms have received training and about fifty flower and cutting farms (80 per cent) were certified as compliant with the Code during the period September 2007 to March 2010. In addition to the local certificate of compliance, several farms are striving to acquire international standards such as MPS and GlobalGAP. So far about 21 farms are believed to have received MPS certificates.

\section{Heterogeneity in firms’ capabilities by marketing channels}

In the previous section we analysed capability building across the sector. In this section we examine if the difference in the level of requirements between marketing channels has led to differences in capabilities between firms supplying mainly to auction and those through the direct sales channel. Although some firms mix both auction and direct sales, firms are predominantly exporting through one of the channels (see Table 3). Based on this observation, we take 70 per cent of direct sales as the threshold for a firm to be categorized as mainly involved in direct sales channel. For example, 39 per cent of firms sold at least 70 per cent of their exports through direct sales in 2007; the other 61 per cent of firms sold through auctions.

The auction market is characterized by loose, market-based trading relationships, which are less strictly coordinated and less buyer driven. In contrast, in the direct sales market, buyers tightly coordinate the value chain. Unlike the auction market, buyers in the direct sales channel strictly apply public standards (such as safety, social or environmental) and impose additional value chain specific standards related to volume, 
quality and timing consistency (Riisgaard, 2009). The implication is that the required capabilities of suppliers should differ by the two marketing channels.

Supermarkets and other retailers in the direct sales chain demand larger varieties of flowers, while auction markets can handle a large volume of one variety. Suppliers involved in direct sales, therefore, need to provide a number of varieties, which in turn necessitates in-house capacity for propagating varieties (Wijnands, van der Lans and Hoobbs, 2006). The need to supply a large number of varieties and fulfill various other requirements in the direct sales chain affects the size of the firm. Involvement in direct sales also demands higher capabilities in expertise, logistics and marketing intelligence than the auction given the specific requirements for consistency in volume, quality and timing. We tested the hypotheses of whether firms mainly engaged in direct sales are more likely to produce more varieties, have farms larger in size, are more vertically integrated, and have better human and logistical capabilities, and found them to be true (Table 4). However, we cannot disentangle whether the marked difference in the capabilities between the firms operating through the two marketing channels were present upon entry or occurred as a result of efforts to upgrade.

Table 4 gives the test result of comparing the two groups of firms in terms of number of varieties, size, human capital, and other logistic related variables, most of which are statistically significant. The number of varieties produced and exported by the group of firms exporting mainly through direct sales channel is five times higher than those in auction. Firms mainly in the direct sales channel are on average located in higher altitude than the farms supplying the auction. The firms in these two market channels also differ in terms of owning a propagation facility. The ratio of firms in the 
direct sales channel that have own propagation facility is more than double $(0.48)$ the ratio of firms mainly supplying the auction (0.18).

Using employment and land size as a measure of farm size, firms that are involved mainly in direct sales are relatively larger than those engaged mainly through auction. For example, in 2007 the average employment was 389 workers for firms mainly in direct sales and 312 for those in the auction. The average size of land covered with flowers was also slightly higher (11.5 ha) in direct sales than auction firms (10.8 ha).

There are also differences in terms of human capital, logistics, and ICT capabilities by market channel. Firms in direct sales tend to use more foreign expertise. They also rely mainly on their own agents or mother companies for finding marketing information, and are more likely to use websites for their business. Direct sales suppliers are fourtimes more likely to have ever used chartered air cargo in addition to normal arrangements, indicating that direct sales suppliers must meet the required time consistency by making flexible transport arrangements.

\section{Conclusions}

The Ethiopian flower industry emerged at time when the EU market was already characterized by increasingly stringent standards and regulations. Entering into the EU market required a multitude of capabilities at firm, sector and national levels. Several of the required capabilities (for example inputs, facilities and services) were absent or weak in the domestic market when the new activity began. At the initial stage, some of these inputs (for example, skilled personnel, equipment, planting materials, and marketing information) were acquired from abroad from buyers and suppliers. With the 
expansion of the domestic industry and the upgrading efforts of firms, some of these inputs become increasingly available in the domestic market.

Several of the other capabilities, however, required coordination among the firms and public and private partnership in order to develop them. The industry association was instrumental in resolving many of these coordination problems and took various initiatives. It established export handling/forwarding and input supplier companies and continues to organize external training to address the shortage of skilled labour in the domestic market. It was actively involved in the market diversification efforts and also in the formation and implementation of an industry-wide Code of Conduct. Consequently, the majority of firms became certified to international quality standards. The association has also played an important role in building trust between the public and private sector and attracting attention and support from the government.

Likewise, the government's role was very crucial, particularly in the air transport coordination between the exporters and the public owned carrier, Ethiopian Airlines. This was in addition to its provision of land and long-term credit at generous terms. The government, with support of donors, has been involved in other capacity building activities such as training (degree programs and practical training centers on horticulture), quality control and certification services. However, some of the essential infrastructure and services (for example cool chain and phytosanitary services) remain underdeveloped, and the link between the industry and public research and development $(\mathrm{R} \& \mathrm{D})$ is weak. These weaknesses might hamper the future growth of the sector if they are not quickly addressed.

These findings have broad implications for the export promotion activities of many developing countries. The pattern of increasing power of global buyers and standards in 
developed country markets looks irreversible. Instead, it is getting more sophisticated and extended to other products or market segments. This means even more capabilities, not only with regard to production but also in terms of marketing and logistics, are needed at the supply base to be able to break into and survive in the increasingly globalized market. The way forward for developing countries with their export drive is to improve these capabilities on a continuous basis to cope with the rapidly changing international business environment. This endeavour cannot be left to the market and individual firms alone, but requires coordination between firms and within industries and strong private-public partnerships. This paper also demonstrates that understanding the formation of new export activities requires a broad analytical framework that combines the market and non-market linkages as well as vertical and horizontal linkages. 


\section{References}

Altenburg, T. (2006) Governance patterns in value chains and their development impact. The European Journal of Development Research, 18(4), pp. 498-521.

Arbeláez, Maria Angelica, Mercela Melendez and Nicolas Leon (2007) The Emergency of New Successful Export Activities in Colombia. Inter-American Development Bank Project Latin America Research Network, Washington DC., USA. http://idbgroup.org/res/ laresnetwork/projects/pr284finaldraft.pdf.

Belwal, R. and Chala, M. (2008) Catalysts and barriers to cut flower export: A case study of Ethiopian floriculture industry. International Journal of Emerging Markets, 3(2), pp.216 - 235.

Bergek, A., Jacobsson, S., Carlsson, B., Lindmark, S. and Rickne A. (2008) Analyzing the functional dynamics of technological innovation systems: a scheme of analysis. Research Policy, 37 (3), pp. 407-429.

Centre for the promotion of exports from developing countries, CBI, (2007) CBI market survey: the cut flower and foliage market in the EU. Online http://www.ibce.org.bo/Documentos/market_flower.pdf

Dolan, C. and Humphrey, J. (2000) Governance and trade in fresh vegetables: the impact of UK supermarkets on the African horticulture industry. Journal of Development Studies, 37 (2), 147-76.

Edquist, C. (2004) Systems of innovation: perspectives and challenges. in: J. Fagerberg, D.C. Mowery, and R.R. Nelson, (eds.) The Oxford Handbook of Innovation (Oxford University Press, Oxford), pp. 181-208.

Ethiopian Horticulture Producers and Exporters Association, EHPEA, (2011) Code of Practice for Sustainable Flower Production” Version 2.0 Issue Date March 2011. 
http://www.ehpea.org/documents/Code\%20Version\%20March\%202011\%20copy \%20for\%20Web\%20Site.pdf.

Gebreeyesus, M. and Iizuka, M. (2010) Discovery of the flower industry in Ethiopia: experimentation and coordination. Working Paper No. 2010-05, United Nations University (UNU-MERIT), Maastricht.

Gereffi, G., Humphrey, J. and Sturgeon T. (2005) The Governance of Global Value Chains. Review of International Political Economy, 12(1) February, 78-104.

Gibbon, P. and Ponte, S. (2005) Trading Down: Africa, value chains, and the global economy, (Philadelphia, Temple University Press).

Glenn, H. (2010) Ethiopian Horticulture Producers and Exporters Association (EHPEA) code of practice implementation report. Mimeo, EHPEA, Addis Ababa.

Hall, A, Mytelka, L. and Oyelaran-Oyeyinka, B. (2007) Concepts and guidelines for diagnostic assessments of agricultural innovation capacity. Mimeo, UNUINTECH, Maastricht.

Hausmann, R. and Rodrik D. (2006) Doomed to choose: industrial policy as predicament. Paper prepared for the first Blue Sky seminar organized by the Center for International Development at Harvard University on September 9, 2006.

Hekkert, M, R. Suurs, S. Negro, S. Kuhlmann, and R. Smits (2007) Functions of innovation systems: a new approach for analyzing technical change. Technological Forecasting \& Social Change, 74 (4): 413-432.

Henson S. and Jaffee, S. (2006) Food safety standards and trade enhancing competitiveness and avoiding exclusion of developing countries. The European Journal of Development Research, 18(4), pp. 593 - 621. 
Humphrey J. and Schmitz, H. (2004) Governance in global value chains. In: H. Schmitz (ed.) Local Enterprises in the Global Economy: (Cheltenham, Edward Elgar), pp. 95-109.

Jaccobson, S. and Bergek, A. (2006) A framework for guiding policy-makers interning in emerging innovation systems in 'catching-up countries. The European Journal of Development Research, 18 (4):687-707.

Jaffee, S. (2003) From challenge to opportunity: transforming Kenya’s fresh vegetable trade in the context of emerging food safety and other standards in Europe. Discussion Paper 1, Agricultural and Rural Development, The World Bank, Washington DC.

Joosten, F. (2007) Development Strategy for the Export-Oriented Horticulture in Ethiopia. Report commissioned by the industry association and Netherlands Embassy in Addis Ababa. http://library.wur.nl/way/bestanden/clc/1891396.pdf.

Labaste, P. (ed.) (2005) The European Horticulture Market: Opportunities for Sub-

Saharan African Exporters. Working Paper No. 63, The World Bank, Washington, D.C.

Lubelo, T. (2010) The status of Post-Harvest and Transport Technologies for Horticulture produces in Ethiopia” mimeo Ethiopian Horticulture Development Agency (EHDA). http://www.globalhort.org/media/uploads/File/ Video\%20Conferences/Ethiopia\%20Post\%20Harvest\%20Position.pdf.

Maertens, M. and Swinnen, J.F.M. (2006) Standards as barriers and catalysts for trade and poverty reduction. Paper presented at the $26^{\text {th }}$ conference of International Association of Agricultural Economists, Australia, August 12-18. 
Melese, A. and Helsing, A.H.J. (2010) Endogenisation or enclave formation? The development of the Ethiopian cut flower industry. Journal of Modern African Studies, 48(1), pp. 35-66.

Riisgaard, L. (2009) Global value chains, labour organization and private social standards: lessons from East African cut-flower industries. World Development, 37(2), pp. 326-40.

United Nations Conference on Trade and Development, UNCTAD (2008) Export performance following trade liberalization: some patterns and policy perspectives, Economic Development in Africa, 2008 series, UNCTAD, Geneva. http://www.unctad.org/en/docs/gdsafrica20031_en.pdf.

United Nations Industrial Development Organization, UNIDO, (2005) Capability building for catching-up; historical, empirical and policy dimensions. Industrial Development Report 2005, Vienna.

Whitaker, M. and Kolavalli, S. (2006) Floriculture in Kenya, in: Vandana Chandra (ed) Technology, Adoption, and Exports: How Some Developing Countries Got It Right (Washington: the World Bank).

Wijnands, J. (2005) Sustainable International Networks in the flower industry: bridging empirical findings and theoretical approaches. International Society for Horticulture Science, Scripta Horticulture no. 2, The Hague.

Wijnands, J., K. Lans, van der and Hobbs, J. (2006) International flower networks: Transparency and Risks in Marketing Channel Choice. Presented at the $99^{\text {th }}$ EAAAE Seminar 'Trust and risk in business networks', Bonn, Germany, February $8-10$. 
Table 1 number of farms, exported stems and revenue by year

\begin{tabular}{|c|c|c|c|c|c|c|c|c|c|}
\hline & \multicolumn{9}{|c|}{ year } \\
\hline & 2000 & 2001 & 2002 & 2003 & 2004 & 2005 & 2006 & 2007 & 2008 \\
\hline \multicolumn{10}{|l|}{ Number of farms* } \\
\hline Domestic owned & 2 & 1 & 2 & 3 & 4 & 15 & 20 & 24 & \\
\hline Foreign owned & 1 & 1 & 1 & 2 & 4 & 8 & 18 & 28 & \\
\hline Joint venture & 0 & 0 & 0 & 0 & 2 & 8 & 15 & 15 & \\
\hline All & 3 & 2 & 3 & 5 & 10 & 31 & 53 & 67 & 81 \\
\hline Growth (\%) & & -33.3 & 50.0 & 66.7 & 100.0 & 210.0 & 71.0 & 26.4 & 20.9 \\
\hline \multicolumn{10}{|l|}{ Exports to EU-27 } \\
\hline million USD** & 0.5 & 0.9 & 1.3 & 3.7 & 6.5 & 12.0 & 27.4 & 56.6 & 98.7 \\
\hline Growth (\%) & & 64.8 & 47.9 & 186.1 & 74.9 & 84.6 & 128.2 & 106.4 & 74.4 \\
\hline \multicolumn{10}{|l|}{ Exports to EU-27 } \\
\hline million kg weight** & 0.2 & 0.2 & 0.3 & 0.7 & 1.4 & 3.5 & 7.9 & 16.0 & 21.8 \\
\hline Growth (\%) & & 6.2 & 9.9 & 162.2 & 105.8 & 156.6 & 122.8 & 102.1 & 36.2 \\
\hline
\end{tabular}




\section{Table 2 Source inputs and trainings to workers}

\begin{tabular}{|c|c|c|c|c|c|c|}
\hline \multirow{2}{*}{$\begin{array}{l}\text { Source of inputs (\%) of } \\
\text { procurement }\end{array}$} & \multicolumn{2}{|c|}{ planting materials } & \multicolumn{2}{|c|}{ fertilizer } & \multicolumn{2}{|c|}{ chemicals } \\
\hline & 2005 & 2007 & 2005 & 2007 & 2005 & 2007 \\
\hline Local & 16.1 & 50.3 & 9.7 & 30.0 & 12.4 & 33.6 \\
\hline Import through traders & 4.3 & 0.1 & 39.8 & 41.2 & 44.2 & 44.9 \\
\hline \multirow[t]{4}{*}{ Import directly } & 73.0 & 38.3 & 49.4 & 30.5 & 44.9 & 23.2 \\
\hline & \multicolumn{6}{|c|}{ Trainings provided to in 2007 for } \\
\hline & \multicolumn{2}{|c|}{ production workers } & \multicolumn{2}{|c|}{ agro-specialists } & \multicolumn{2}{|c|}{ marketing workers } \\
\hline & in-house & outside & in-house & outside & in-house & outside \\
\hline $\begin{array}{l}\% \text { of firms provided } \\
\text { training }\end{array}$ & 81.3 & 48.4 & 50.0 & 48.4 & 12.5 & 9.4 \\
\hline $\begin{array}{l}\% \text { of workers received } \\
\text { training (average) }\end{array}$ & 70 & 11 & 72 & 49 & 78 & 40 \\
\hline
\end{tabular}

Source: own survey. 
Table 3 Sales by marketing channel (2007)

\begin{tabular}{|c|c|c|c|c|c|c|c|c|}
\hline \multirow{4}{*}{$\begin{array}{l}\% \text { sales through } \\
\text { each channel }\end{array}$} & \multicolumn{8}{|c|}{ Number and percentage of firms made sales through } \\
\hline & \multirow{2}{*}{\multicolumn{2}{|c|}{$\frac{\text { domestic market }}{2007}$}} & \multirow{2}{*}{\multicolumn{2}{|c|}{$\begin{array}{c}\text { Holland auction } \\
\text { (export) }\end{array}$}} & \multicolumn{4}{|c|}{ direct sales (export) } \\
\hline & & & & & \multicolumn{2}{|c|}{ Initial year } & \multicolumn{2}{|c|}{2007} \\
\hline & freq & $\%$ & freq & $\%$ & freq & $\%$ & freq & $\%$ \\
\hline 0 & 52 & 81.3 & 22 & 34.4 & 31 & 50 & 27 & 42.2 \\
\hline $1-35$ & 11 & 17.2 & 5 & 7.9 & 8 & 12.9 & 12 & 18.8 \\
\hline $36-70$ & 0 & 0.0 & 2 & 3.1 & 0 & 0 & 0 & 0.0 \\
\hline 70 and above & 1 & 1.6 & 35 & 54.7 & 23 & 37.1 & 25 & 39.1 \\
\hline All & 64 & 100 & 64 & 100 & 62 & & 64 & 100 \\
\hline
\end{tabular}


Table 4 Size, number of varieties, personnel and logistics by market channel in 2007

\begin{tabular}{|c|c|c|c|c|}
\hline \multirow[b]{2}{*}{ variables } & \multicolumn{3}{|c|}{ Over marketing channel } & \multirow{2}{*}{$\begin{array}{c}\text { Testing mean } \\
\text { difference } \\
\text { p-value }\end{array}$} \\
\hline & statistic & $\begin{array}{l}\text { Mainly } \\
\text { auction }\end{array}$ & $\begin{array}{c}\text { Mainly } \\
\text { direct sales }\end{array}$ & \\
\hline employment total & mean & $\begin{array}{l}311.6 \\
(29.7)\end{array}$ & $\begin{array}{c}388.6 \\
(55.45)\end{array}$ & 0.09 \\
\hline land size ha & mean & $\begin{array}{l}10.81 \\
(1.46)\end{array}$ & $\begin{array}{l}11.52 \\
(1.38)\end{array}$ & 0.036 \\
\hline Number of varieties & mean & $\begin{array}{c}6.8 \\
(0.706)\end{array}$ & $\begin{array}{c}33.8 \\
(13.87)\end{array}$ & 0.09 \\
\hline Altitude (meters above sea level) & mean & $\begin{array}{l}2062.2 \\
(65.02)\end{array}$ & $\begin{array}{l}2107.9 \\
(81.0)\end{array}$ & 0.33 \\
\hline $\begin{array}{l}\text { Use of foreign experts (man- } \\
\text { months) }\end{array}$ & mean & $\begin{array}{l}12.622 \\
(3.246)\end{array}$ & $\begin{array}{c}27.26 \\
(7.654)\end{array}$ & 0.016 \\
\hline $\begin{array}{l}\text { Source of information own agent } \\
\text { or mother company }\end{array}$ & ratio & 0.315 & 0.56 & 0.054 \\
\hline Use website for business & ratio & 0.16 & 0.32 & 0.13 \\
\hline Ever used chartered air cargo & ratio & 0.08 & 0.32 & 0.014 \\
\hline $\begin{array}{l}\text { Share of farms with own } \\
\text { propagation facility }\end{array}$ & ratio & 0.18 & 0.48 & 0.012 \\
\hline
\end{tabular}

Source: own survey. Figures in parentheses are standards errors. 